\title{
Education: public service output, input and productivity
}

Allan Baird, Joseph Haynes, Fiona Massey and Richard Wild

Office for National Statistics

\section{Summary}

This article presents the latest estimates of publicly funded education productivity in the United Kingdom. From 1996 to 2009 productivity declined by 0.1 per cent, but this marginal fall overall masks three periods of greater change. From 1996 to 1999, productivity grew by 7.1 per cent, with an annual average increase of 2.3 per cent. In this period there was strong output growth, due to growth in the school age population, but only weak growth in inputs. From 1999 to 2007, productivity fell by 9.4 per cent, an annual average fall of 1.2 per cent. Growth in school attendance, once adjusted for quality, was outstripped by a sharp rise in inputs, mainly through the employment of more school support staff. From 2007 to 2009, productivity grew by 2.9 per cent, with an annual average increase of 1.4 per cent, as output grew faster than inputs, due mainly to relatively large improvements in pupil attainment at age 15/16 in England and Wales.

\section{Introduction}

This article presents the latest estimates of multi-factor productivity growth in publicly funded education services - which are equal to the growth in the ratio of the volume of output to the volume of inputs. The estimates presented in this article are constructed in the same way as those presented in Total Public Service Output, Inputs and Productivity (ONS 2010a) from 1997 to 2008, except that this article extends the scope of Further Education coverage from those aged under-19 to all ages. It also presents more detailed analysis and provides estimates from 1996 to 2009 using the latest data.

It is unlikely that a single measure of productivity change will ever capture all the costs and benefits of education. The methods give approximations to a complex reality and estimates therefore need to be interpreted carefully. The Atkinson Review (2005) recommends that a process of triangulation is undertaken when new output and productivity figures are produced for government services. This involves presenting independent corroborative evidence to provide a context for estimates of output (in terms of quantity and quality) and inputs. Therefore, this article also 
provides an update of triangulation evidence previously presented in Public Service Output, Input and Productivity: Education (ONS 2009).

The article proceeds as follows. The next section looks at the measurement of education output in the UK - consisting of quantity and quality. Next, the focus turns to measuring the components of education inputs, before output and input estimates are combined to estimate productivity growth. The final section briefly discusses further development work planned for these statistics.

\section{Output of education in the UK}

\section{Education quantity}

Education output has two components:

- Quantity (which is adjusted by)

- Quality

This section considers the quantity component. Quantity is the sum of publicly funded education services delivered before quality adjustment and, as recommended by Eurostat (2001), is measured using pupil and student numbers. In this article, education quantity includes full-time equivalent (FTE), publicly funded pupils and students in:

- government-maintained primary, secondary and special schools, adjusted for attendance

- further education colleges

- pre-school education, including places procured from the private, voluntary and independent sector; and

- higher education studying for initial teacher training and health professional courses funded directly by government

In the previous education productivity article (ONS 2009) publicly-funded further education courses for those aged under-19 were included since it was logical to consider them with pupils aged sixteen to eighteen in school sixth forms in a measure of education productivity. This differed from National Accounts measures where, although publicly funded educational institutions up to the age of 16 are classified to the public sector, further education and sixth form colleges were classified in the Non-Profit Institutions Serving Households (NPISH) sector. ONS has recently reviewed the classification of further education institutions in the National Accounts, resulting in a decision to reclassify all further education institutions in the UK into the (public) general government sector (Stokoe 2010). Development work has also been completed so that further education for all ages can be included in this article. In the future National Accounts will have the same coverage as this article. The quantity measure for each of the components of education output is based on pupil or student numbers in each academic year. Box 1 provides an overview on recent changes to the UK school age population.

Table 1 summarises full-time equivalent pupil numbers by type of education and by country, on an academic-year basis. 


\section{Full-time equivalent pupil/student numbers by provider and country, 1995/96-2008/09}

United Kingdom

Index numbers, $1995 / 96=100$

\begin{tabular}{|c|c|c|c|c|c|c|c|c|c|c|c|c|c|c|c|c|c|}
\hline & 1995/96 & 1996/97 & $1997 / 98$ & 1998/99 & 1999/00 & 2000/01 & $2001 / 02$ & $2002 / 03$ & $2003 / 04$ & $2004 / 05$ & $2005 / 06$ & $2006 / 07$ & $2007 / 08$ & 2008/09 & $\begin{array}{c}\text { Pupil } \\
\text { numbers in } \\
1995 / 96^{5}\end{array}$ & $\begin{array}{c}\text { Pupil } \\
\text { numbers in } \\
2008 / 09\end{array}$ & $\begin{array}{c}\text { Average } \\
\text { annual \% } \\
\text { change }\end{array}$ \\
\hline \multicolumn{18}{|l|}{ By provider } \\
\hline $\begin{array}{l}\text { Maintained pre- } \\
\text { school }\end{array}$ & 100.0 & 101.3 & 101.5 & 104.9 & 103.7 & 106.2 & 103.1 & 102.3 & 99.4 & 96.7 & 99.5 & 101.5 & 102.4 & 103.1 & 250,300 & 258,000 & 0.2 \\
\hline PVI pre-schools & - & 100.0 & 102.8 & 118.8 & 163.2 & 251.3 & 320.7 & 419.7 & 439.7 & 446.4 & 452.6 & 473.7 & 480.5 & 487.0 & 55,900 & 272,400 & 14.1 \\
\hline Primary School & 100.0 & 100.7 & 101.2 & 101.0 & 100.7 & 99.9 & 99.1 & 98.0 & 96.7 & 95.6 & 94.2 & 93.0 & 92.4 & 91.9 & $4,938,800$ & $4,537,700$ & -0.6 \\
\hline $\begin{array}{l}\text { Secondary } \\
\text { Schools }\end{array}$ & 100.0 & 101.0 & 101.8 & 103.2 & 104.9 & 106.5 & 107.4 & 108.6 & 109.2 & 108.8 & 108.4 & 107.2 & 105.3 & 103.4 & $3,677,400$ & $3,803,300$ & 0.3 \\
\hline Special Schools & 100.0 & 100.1 & 100.7 & 100.7 & 99.7 & 98.9 & 97.8 & 97.0 & 94.8 & 93.2 & 92.3 & 92.3 & 92.2 & 92.9 & 107,700 & 100,100 & -0.6 \\
\hline $\begin{array}{l}\text { CTC/ } \\
\text { Academies }\end{array}$ & 100.0 & 106.6 & 110.2 & 112.9 & 115.7 & 117.0 & 120.5 & 141.2 & 185.3 & 220.5 & 262.7 & 369.8 & 560.4 & 870.7 & 14,300 & 124,800 & 18.1 \\
\hline $\begin{array}{l}\text { Initial Teacher } \\
\text { Training }\end{array}$ & 100.0 & 96.0 & 89.8 & 83.9 & 77.7 & 79.6 & 81.7 & 85.4 & 88.7 & 88.7 & 88.8 & 92.6 & 86.8 & 85.8 & 71,700 & 61,500 & -1.2 \\
\hline $\begin{array}{l}\text { Health } \\
\text { Professional } \\
\text { Activity }\end{array}$ & 100.0 & 107.3 & 116.4 & 129.8 & 142.7 & 155.5 & 168.0 & 185.9 & 204.7 & 219.7 & 227.1 & 224.6 & 208.4 & 201.6 & 53,000 & 106,800 & 5.5 \\
\hline $\begin{array}{l}\text { Further } \\
\text { Education }\end{array}$ & 100.0 & 105.2 & 103.2 & 100.3 & 100.1 & 100.4 & 106.0 & 109.8 & 117.5 & 117.3 & 113.9 & 107.6 & 106.9 & 105.7 & $1,189,100$ & $1,256,800$ & 0.4 \\
\hline By country & & & & & & & & & & & & & & & & & \\
\hline England & 100.0 & 101.5 & 101.9 & 102.2 & 102.7 & 103.5 & 104.6 & 105.8 & 106.7 & 106.3 & 105.3 & 103.7 & 103.0 & 102.5 & $8,574,500$ & $8,785,900$ & 0.2 \\
\hline Wales $^{2}$ & 100.0 & 100.5 & 101.1 & 101.0 & 101.6 & 102.2 & 102.2 & 103.2 & 102.8 & 101.6 & 100.8 & 99.4 & 98.2 & 97.1 & 555,700 & 539,600 & -0.2 \\
\hline Scotland ${ }^{3}$ & 100.0 & 100.6 & 100.0 & 101.4 & 103.3 & 105.0 & 105.3 & 104.8 & 104.0 & 102.5 & 101.5 & 101.3 & 99.5 & 98.3 & 848,500 & 834,000 & -0.1 \\
\hline $\begin{array}{l}\text { Northern } \\
\text { Ireland }\end{array}$ & 100.0 & 100.6 & 100.1 & 99.5 & 99.4 & 99.3 & 99.4 & 99.3 & 98.9 & 98.1 & 97.5 & 96.4 & 95.7 & 95.4 & 379,500 & 362,100 & -0.4 \\
\hline UK & 100.0 & 101.4 & 101.7 & 101.9 & 102.6 & 103.4 & 104.4 & 105.4 & 106.0 & 105.4 & 104.4 & 103.0 & 102.2 & 101.6 & $10,358,200$ & $10,521,500$ & 0.1 \\
\hline
\end{tabular}

1. City Technology Colleges from 1988 and Academies from 2002 in England only. Of the 15 original City Technology Colleges, 12 have now converted to Academy status.

2. Includes estimates for Wales for private, voluntary and independent sector pre-school numbers and to $1997 / 98$ for health professional activity

3. Includes estimates for Scotland for maintained pre-school numbers from registration numbers and to 2002/03 for health professional activity

4. Northern Ireland private, voluntary and independent sector pre-school data for 1996/97

5. Includes private, voluntary and independent pre-school data for 1996/97

Source: Department for Education, Welsh Assembly Government, Scottish Executive, Northern Ireland Statistics and Research Agency.

Pupil numbers in primary, secondary and special schools throughout the UK and England-only city technology colleges (CTCs) and academies are adjusted for attendance, in order to reflect more accurately the quantity of education services delivered.

No attendance adjustments are currently made to the pupils/students in UK pre-school education, initial teacher training (ITT), health professional training and further education (FE). Box 2 provides some further discussion on the adjustment for attendance. 


\section{Box 1 UK school age population}

The quantity measure for education covers eight categories of publicly funded education including pre-schools, primary and secondary schools, further education and training places for health professionals and teachers. Pupils in compulsory schooling (aged 5-16) account for around fourfifths of the total. As school education is compulsory between the ages of 5 and 16, numbers attending primary and secondary schools are largely driven by population changes. Also, the introduction of grants for a number of pre-school education sessions per week has led to a rapid increase in users of nursery and pre-school places.

Figure 1 in this box shows how numbers of children in different age groups have changed since 1996. There has been a marked increase in 17-18 year old children, but declines in numbers of pre-school and primary school age children.

\section{Figure $1 \quad$ UK school-age population estimates by age group 1996- 2009}

Index numbers, $1996=100$

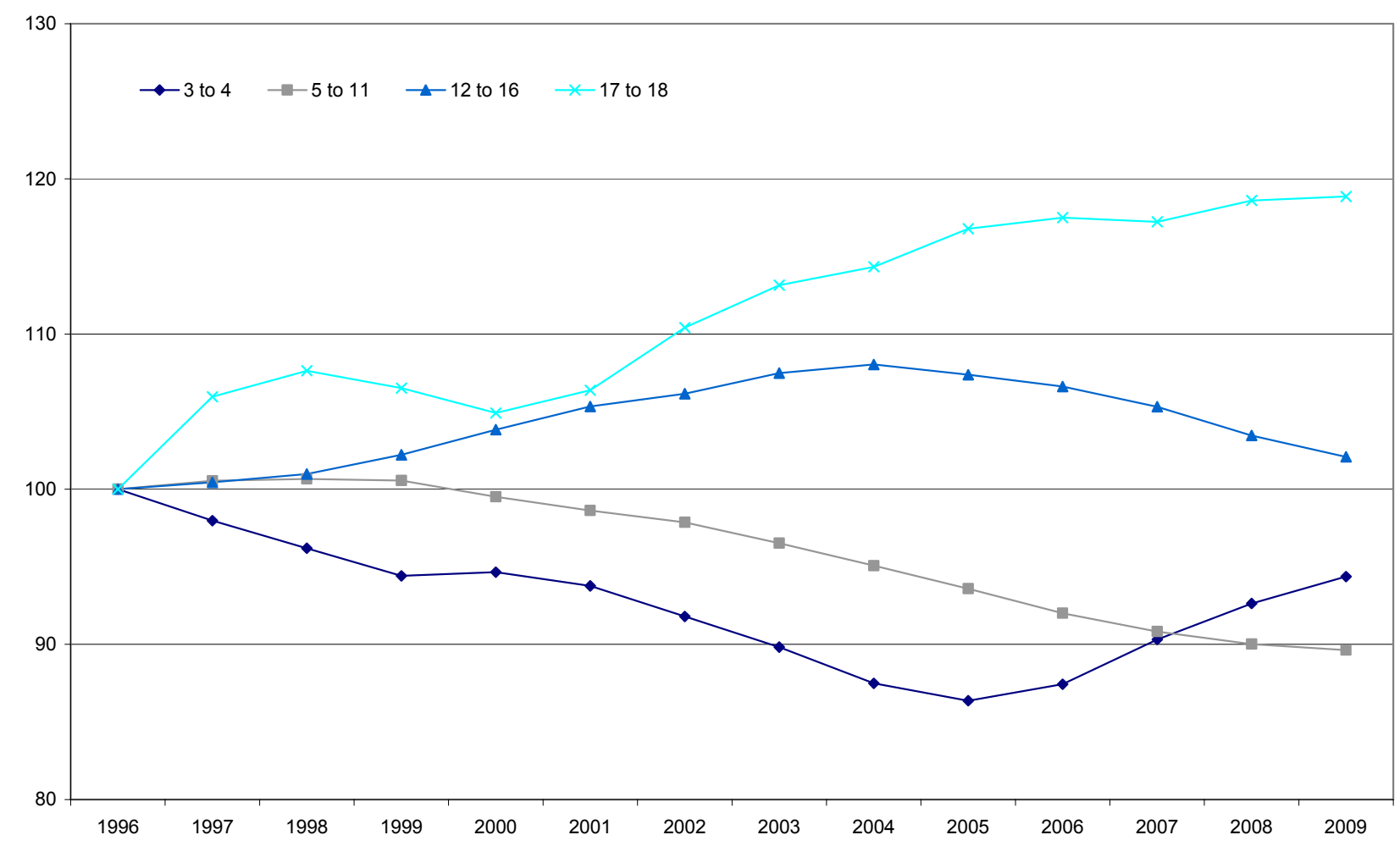

Source: Office for National Statistics 


\section{Box $1 \quad$ UK school age population}

Figure 2 shows how the population has changed within the UK. Overall, numbers of 5-16 year olds increased between 1996 and 2003, but by 2009 had declined to around 5 per cent below their 1996 level, with larger and steadier falls in Wales, Scotland and Northern Ireland.

\section{Figure 2 UK school-age (5-16) population estimates by country, 1996-2009}

Index numbers, $1996=100$

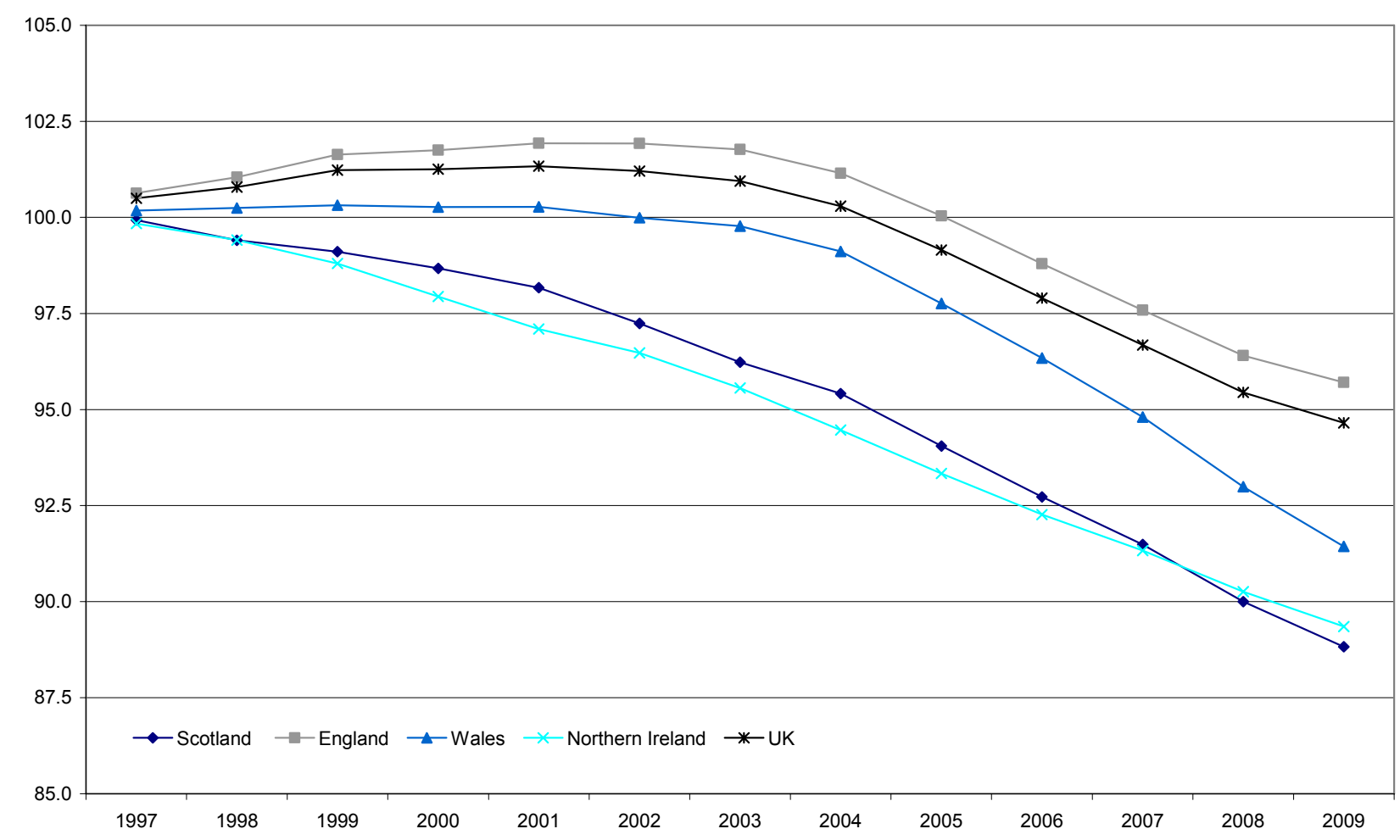

Source: Office for National Statistics

Going forward, the live birth rate has been increasing in all countries of the UK since 2003, making a positive impact on output growth from 2006 onwards when the first children became eligible for publicly funded nursery provision. 


\section{Box 2 Are attendance-adjusted pupil numbers a good proxy for quantity?}

Eurostat (2001) recommends that school education output should be measured either using pupil hours or alternatively, pupil numbers where hours of tuition are broadly consistent over time. The current ONS measure is based on pupil numbers but, following Atkinson (2005), adjusts these figures for attendance to more accurately approximate the amount of teaching services delivered. However, the measure still has the potential to miss variation in school output for two reasons:

- There is no legislation covering either the minimum or maximum number of teaching hours delivered by providers at each stage in any of the UK countries, only guidelines ${ }^{1}$

- The minimum number of half-day sessions (morning/afternoon) to be scheduled in each academic year is covered by legislation but the actual number delivered may vary due to external factors such as poor weather, industrial action, health-based closures or localised facility problems

\section{Evidence on teaching hours}

Very few data are currently available allowing comparisons of teaching hours delivered by provider and by country. In guidelines for England, published in 1990, a small sample of then-recently inspected schools is included. This shows, on a weekly basis, a variation of up to 16 per cent in primary school lesson time, and up to 17 per cent in secondary schools. When including nonlesson time (such as assembly, registration and breaks), the respective maximum variations were lower - at 14 per cent and 9 per cent - but still large enough to imply potential error in the attendance-based estimates, although the age of the sample means that it is only illustrative at best.

\section{Evidence on half-day sessions delivered}

All four UK countries collect academic year data on the total possible number of half-day sessions and the total number of half-day sessions attended in order to calculate attendance and absence rates. Total possible half-day sessions is affected by factors including those outlined before, while the proportion of half-day sessions attended is affected by authorised and unauthorised absences, but the formula means that it is possible to have the same absence rate in different years despite changes in the total number of half-day sessions offered.

For example, if a school with ten pupils provides 380 sessions per pupil, or 3,800 sessions in total, in $2008 / 09$ of which the pupils attend 3,420 , the absence rate is 10 per cent. If, however, in $2009 / 10$ the school provides 370 sessions per pupil (3,700 in total) of which the pupils attend 3,330 , the absence rate remains unchanged at 10 per cent. Using the current methodology, pupil numbers, pupil attendance ([1-absence] x pupil numbers) and therefore education quantity would have all remained static - despite a fall in total sessions delivered of around 3 per cent. 


\section{Box 2 Are attendance-adjusted pupil numbers a good proxy for quantity?}

Half-day sessions time series data is available for England, Wales and Scotland, which has been used to create estimates of education quantity for primary and secondary schools, with existing estimates shown alongside for comparison (Table 1). Data are shown from academic year $2004 / 05$ onwards as various definitional changes by country occurred in earlier years.

\section{Table $1 \quad$ Half-day sessions for primary and secondary schools}

Great Britain

Index numbers, $2004 / 05=100$

\begin{tabular}{|c|c|c|c|c|c|c|}
\hline & & England & & Scotland & & Wales \\
\hline & Sessions measure & $\begin{array}{c}\text { Attendance-adjusted pupil } \\
\text { numbers }\end{array}$ & Sessions measure & $\begin{array}{c}\text { Attendance-adjusted pupil } \\
\text { numbers }\end{array}$ & Sessions measure & $\begin{array}{c}\text { Attendance-adjusted pupil } \\
\text { numbers }\end{array}$ \\
\hline \multicolumn{7}{|l|}{ Primary } \\
\hline $2004 / 05$ & 100.0 & 100.0 & 100.0 & 100.0 & 100.0 & 100.0 \\
\hline $2005 / 06$ & 97.5 & 98.3 & 97.7 & 98.0 & 98.8 & 97.4 \\
\hline $2006 / 07$ & 96.8 & 97.8 & 95.6 & 96.2 & 97.4 & 96.0 \\
\hline $2007 / 08$ & 94.7 & 97.2 & 94.6 & 94.4 & 95.3 & 95.0 \\
\hline $2008 / 09$ & 93.7 & 96.8 & 92.2 & 93.2 & 92.7 & 92.4 \\
\hline \multicolumn{7}{|c|}{ Secondary } \\
\hline $2004 / 05$ & 100.0 & 100.0 & 100.0 & 100.0 & 100.0 & 100.0 \\
\hline $2005 / 06$ & 99.8 & 99.3 & 99.4 & 99.3 & 97.2 & 97.4 \\
\hline $2006 / 07$ & 98.9 & 98.5 & 98.2 & 98.4 & 95.9 & 96.0 \\
\hline $2007 / 08$ & 96.8 & 97.2 & 97.6 & 97.3 & 93.5 & 95.0 \\
\hline $2008 / 09$ & 96.0 & 95.5 & 95.9 & 95.6 & 91.7 & 92.4 \\
\hline
\end{tabular}

Source: Office for National Statistics

The comparison shows that, in general, there are only slight differences between sessions-based and attendance-based quantity measures, but that differences are more pronounced at primary level, particularly for England, which is the largest single component of total quantity.

The current methodology therefore still appears to be reasonably accurate overall. But, while the data above only cover a short period, they suggest that further work is needed. If data can be adjusted to allow longer comparisons over time the evidence can then be used to decide whether or not there is a need to adjust not only for attendance, but changes in the underlying amount of education services being delivered.

1. For example see: http://www.teachernet.gov.uk/management/atoz///lengthofschoolday/ 
Table 2 summarises the unweighted quantity indices for each education component, which are the indices shown in Table 1, adjusted where applicable for attendance (figures in bold), and converted from academic to calendar years.

\section{Table $2 \quad$ Full-time equivalent pupil/student attendances by provider and country, 1995/96-2008/09}

United Kingdom

Index numbers, $1995 / 96=100$

\begin{tabular}{|c|c|c|c|c|c|c|c|c|c|c|c|c|c|c|c|c|c|}
\hline & 1995/96 & 1996/97 & 1997/98 & 1998/99 & $1999 / 00$ & $2000 / 01$ & 2001/02 & $2002 / 03$ & $2003 / 04$ & $2004 / 05$ & $2005 / 06$ & $2006 / 07$ & $2007 / 08$ & $2008 / 09$ & $\begin{array}{c}\text { Pupil } \\
\text { numbers } \\
\text { in } \\
1995 / 96^{5}\end{array}$ & $\begin{array}{c}\text { Pupil } \\
\text { numbers } \\
\text { in } \\
2008 / 09\end{array}$ & $\begin{array}{c}\text { Average } \\
\text { annual } \\
\% \\
\text { change }\end{array}$ \\
\hline \multicolumn{18}{|l|}{ By provider } \\
\hline $\begin{array}{l}\text { Maintained } \\
\text { pre-schools }\end{array}$ & 100.0 & 101.3 & 101.5 & 104.9 & 103.7 & 106.2 & 103.1 & 102.3 & 99.4 & 96.7 & 99.5 & 101.5 & 102.4 & 103.1 & 250,300 & 258,000 & 0.2 \\
\hline $\begin{array}{l}\text { PVI pre- } \\
\text { schools }\end{array}$ & - & 100.0 & 102.8 & 118.8 & 163.2 & 251.3 & 320.7 & 419.7 & 439.7 & 446.4 & 452.6 & 473.7 & 480.5 & 487.0 & 55,900 & 272,400 & 14.1 \\
\hline $\begin{array}{l}\text { Primary } \\
\text { School }\end{array}$ & 100.0 & 101.2 & 101.5 & 101.7 & 101.6 & 100.4 & 99.8 & 98.6 & 97.6 & 96.6 & 94.8 & 94.2 & 93.5 & 93.0 & $4,621,600$ & $4,295,800$ & -0.6 \\
\hline $\begin{array}{l}\text { Secondary } \\
\text { Schools }\end{array}$ & 100.0 & 101.4 & 102.3 & 103.8 & 105.9 & 107.0 & 108.2 & 110.0 & 110.8 & 110.8 & 109.9 & 109.1 & 107.7 & 105.9 & $3,322,300$ & $3,518,700$ & 0.4 \\
\hline $\begin{array}{l}\text { Special } \\
\text { Schools }\end{array}$ & 100.0 & 100.5 & 101.0 & 101.2 & 100.8 & 99.0 & 98.5 & 97.8 & 96.1 & 94.5 & 93.4 & 93.4 & 93.4 & 94.0 & 95,200 & 89,500 & -0.5 \\
\hline $\begin{array}{l}\text { CTC/ } \\
\text { Academies }{ }^{1}\end{array}$ & 100.0 & 107.1 & 110.9 & 114.0 & 116.6 & 117.6 & 121.1 & 141.9 & 183.8 & 219.5 & 259.4 & 362.4 & 551.3 & 856.8 & 13,400 & 114,500 & 18.0 \\
\hline $\begin{array}{l}\text { Initial } \\
\text { Teacher } \\
\text { Training }\end{array}$ & 100.0 & 96.0 & 89.8 & 83.9 & 77.7 & 79.6 & 81.7 & 85.4 & 88.7 & 88.7 & 88.8 & 92.6 & 86.8 & 85.8 & 71,700 & 61,500 & -1.2 \\
\hline $\begin{array}{l}\text { Health } \\
\text { Professional } \\
\text { Activity }\end{array}$ & 100.0 & 107.3 & 116.4 & 129.8 & 142.7 & 155.5 & 168.0 & 185.9 & 204.7 & 219.7 & 227.1 & 224.6 & 208.4 & 201.6 & 53,000 & 106,800 & 5.5 \\
\hline $\begin{array}{l}\text { Further } \\
\text { Education }\end{array}$ & 100.0 & 105.2 & 103.2 & 100.3 & 100.1 & 100.4 & 106.0 & 109.8 & 117.5 & 117.3 & 113.9 & 107.6 & 106.9 & 105.7 & $1,189,100$ & $1,256,800$ & 0.4 \\
\hline By country & & & & & & & & & & & & & & & & & \\
\hline England & 100.0 & 101.9 & 102.3 & 102.7 & 103.5 & 103.9 & 105.3 & 106.8 & 108.0 & 107.7 & 106.3 & 105.1 & 104.5 & 104.0 & $8,016,100$ & $8,337,800$ & 0.3 \\
\hline Wales $^{2}$ & 100.0 & 101.0 & 101.4 & 101.5 & 102.4 & 102.6 & 102.9 & 103.7 & 103.4 & 102.1 & 100.9 & 100.1 & 99.0 & 97.9 & 515,900 & 505,100 & 0.2 \\
\hline Scotland $^{3}$ & 100.0 & 101.0 & 100.6 & 102.3 & 104.7 & 106.1 & 106.7 & 106.3 & 106.0 & 104.3 & 103.4 & 103.5 & 101.7 & 100.6 & 783,800 & 788,500 & 0.0 \\
\hline $\begin{array}{l}\text { Northern } \\
\text { Ireland }^{4}\end{array}$ & 100.0 & 100.9 & 100.3 & 99.7 & 99.7 & 99.6 & 99.9 & 99.6 & 99.4 & 98.7 & 97.9 & 96.8 & 96.2 & 96.1 & 356,700 & 342,600 & $\overline{0.3}$ \\
\hline UK & 100.0 & 101.8 & 102.0 & 102.5 & 103.4 & 103.8 & 105.1 & 106.3 & 107.3 & 106.8 & 105.4 & 104.4 & 103.7 & 103.1 & $9,672,400$ & $9,974,100$ & 0.2 \\
\hline
\end{tabular}

1. City Technology Colleges from 1988 and Academies from 2002 in England only. Of the 15 original City Technology Colleges, 12 have now converted to Academy status.

2. Includes estimates for Wales for private, voluntary and independent sector pre-school numbers and to $1997 / 98$ for health professional activity

3. Includes estimates for Scotland for maintained pre-school numbers from registration numbers and to 2002/03 for health professional activity

4. Northern Ireland private, voluntary and independent sector pre-school data for 1996/97

5. Includes private, voluntary and independent pre-school data for 1996/97

Source: Department for Education, Welsh Assembly Government, Scottish Executive, Northern Ireland Statistics and Research Agency. 
Looking at each component:

- The largest observed increase was in CTCs and academies, due to a rapid policy-driven expansion since 2000 although most of this increase came from the conversion of existing English secondary schools.

- Health professional training grew rapidly mainly through an increase in the number of trainee nurses, particularly at degree level.

- Pre-school education also grew rapidly following the introduction of a policy to provide a number of hours of free childcare per week for three- and four-year-olds.

- There was a small increase in further education quantity, with a rise in the number of students taking qualifications suitable for entry into higher education mostly offset by a decline in adult education courses.

- A decrease in the five-to-eleven-year-old population led to a fall in primary school quantity.

- Special schools quantity reduced due to the integration of many children with special needs into mainstream schools.

- The quantity of ITT also fell, primarily due to a shift in demand from three- to one-year courses which reduced the number of students.

Table 3 summarises the relative shares of expenditure on each of the education components over the period 1996 to 2009 .

\section{Table 3 Expenditure-based education weights, 1996-2009}

United Kingdom

\begin{tabular}{|c|c|c|c|c|c|c|c|c|c|c|c|c|c|c|}
\hline & 1996 & 1997 & 1998 & 1999 & 2000 & 2001 & 2002 & 2003 & 2004 & 2005 & 2006 & 2007 & 2008 & 2009 \\
\hline Pre-schools & 1.8 & 1.8 & 1.8 & 2.1 & 2.9 & 3.8 & 3.9 & 4.9 & 4.7 & 5.0 & 5.7 & 5.7 & 5.7 & 5.7 \\
\hline Primary Schools & 39.4 & 39.1 & 40.1 & 38.5 & 37.6 & 37.4 & 37.0 & 36.3 & 35.5 & 35.2 & 35.2 & 35.2 & 35.2 & 35.2 \\
\hline Secondary Schools & 33.5 & 33.7 & 33.3 & 35.9 & 37.6 & 37.6 & 37.7 & 37.6 & 37.4 & 37.3 & 37.4 & 37.4 & 37.4 & 37.4 \\
\hline Special Schools & 6.6 & 6.9 & 6.9 & 7.0 & 6.3 & 5.3 & 5.5 & 4.8 & 5.3 & 5.8 & 5.7 & 5.8 & 5.8 & 5.8 \\
\hline СТC / Academies & 0.2 & 0.2 & 0.2 & 0.2 & 0.2 & 0.2 & 0.2 & 0.3 & 0.4 & 0.4 & 0.6 & 0.8 & 0.8 & 0.8 \\
\hline Initial Teacher Training & 1.2 & 1.2 & 1.0 & 0.9 & 0.8 & 0.7 & 0.7 & 0.6 & 0.6 & 0.6 & 0.6 & 0.6 & 0.6 & 0.6 \\
\hline \multicolumn{15}{|l|}{ Health Professional } \\
\hline Training & 1.6 & 1.8 & 1.9 & 1.8 & 1.8 & 1.7 & 1.7 & 1.8 & 2.0 & 2.1 & 2.0 & 1.9 & 1.9 & 1.9 \\
\hline Further Education & 15.7 & 15.4 & 14.8 & 13.5 & 12.9 & 13.2 & 13.3 & 13.7 & 14.0 & 13.6 & 12.9 & 12.6 & 12.6 & 12.6 \\
\hline Total & 100.0 & 100.0 & 100.0 & 100.0 & 100.0 & 100.0 & 100.0 & 100.0 & 100.0 & 100.0 & 100.0 & 100.0 & 100.0 & 100.0 \\
\hline
\end{tabular}

Source: Office for National Statistics

Schools constitute the largest proportion of expenditure, accounting for around four-fifths of the total in 2009. Between 1996 and 2009, the proportion of expenditure on primary schools, special schools, further education and ITT decreased as the numbers attending fell. Conversely, the proportion of expenditure on pre-schools, secondary schools, CTCs and academies and health professional training increased, as the numbers attending rose. The proportion of expenditure on further education decreased as the increase in publicly funded under-19 courses was offset by a decline in adult education. 
Education quantity is created by weighting together the components in Table 2 by their respective costs. Figure 1 illustrates contributions to total annual quantity growth by component of education in terms of percentage points over the period 1997 to 2009. Between 1997 and 2009 education quantity grew by 6.4 per cent. This growth was driven by positive percentage point contributions of 3.2 from secondary schools, 1.9 from CTCs and academies, 1.5 from pre-school, 1.5 from health professional training and 0.2 from further education. These were partially offset by negative percentage point contributions of 1.5 from primary schools, 0.4 from special schools and 0.2 from initial teacher training. CTCs and academies have made an increasing positive contribution to education quantity growth since academies were established in 2000 , although this is largely a substitution effect for the secondary schools they have replaced.

\section{Figure 1 Contributions to education quantity growth, 1997-2009}

\section{United Kingdom}

Percentage points contribution to total 6.4 per cent growth*

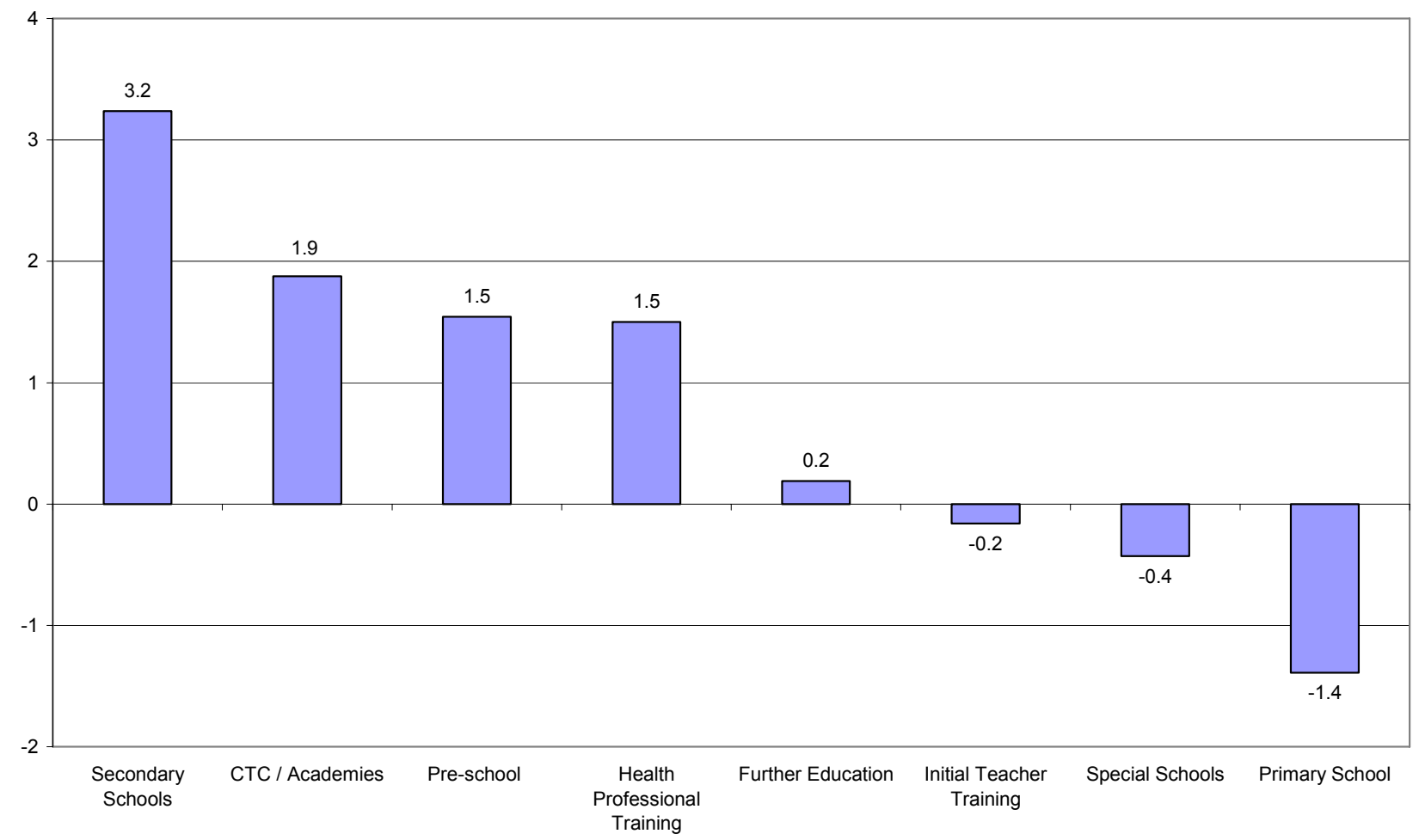

* Figures may not sum due to rounding

Source: Office for National Statistics

\section{Education quality}

Eurostat (2001) and Atkinson (2005) recommend that public service output should be measured in a way that adjusts for quality change. Currently primary schools, secondary schools, CTCs and academies and ITT are quality adjusted. At present there are no quality adjustments for further education, health professional training, special schools and pre-schools. 
The current schools adjustment uses the change in the uncapped average points score (APS) of GCSE and equivalent qualifications in England and Wales and Standard Grades and equivalent qualifications in Scotland to estimate quality change for government-maintained primary and secondary schools and CTCs and academies. A time series of GCSE scores for Northern Ireland is not readily available so the change in APS in Northern Ireland has been approximated by the change in APS in England. Until 2003/04 both the England and Wales APS are calculated using GCSE and GNVQ results only. From 2003/04 onwards, points scores in England and Wales have been published on a wider basis, which includes a range of additional equivalent qualifications. Further information on the quality adjustment for schools output can be found in Methods for public service productivity: quality adjusting school education output, September 2007 (ONS 2007).

The APS for GCSE and equivalent qualifications relates to the attainment of pupils aged 15/16 at the end of Year 11. It is the best current measure for the annual change in the quality of output. It rests on the assumptions that the change in the APS used to approximate quality:

- should be applied to all pupils in primary and secondary schools (from reception class to the end of the sixth form) in the UK and CTCs and academies in England; and

- is an adequate approximation for all education outcomes, for example attainment after 16 and development of wider outcomes such as citizenship

Figure 2 shows the APS used for quality adjustment for schools in England, Wales and Scotland, in academic years. Between 1995/96 and 2008/09, APS in England grew by 46.6 per cent, with an average annual increase of 3.0 per cent. Over the same period, APS in Wales grew by 41.5 per cent, with an average annual increase of 2.7 per cent, and APS in Scotland grew by 16.4 per cent, with an average annual increase of 1.2 per cent. APS in England, Wales and Scotland all grew in $2008 / 09$ when compared to $2007 / 08$, by $6.8,6.5$ and 2.9 per cent respectively.

The differences in APS between England, Wales and Scotland may result from different policy drives. In addition to any actual change in quality of education service being delivered, the differences could reflect:

- relative starting point

- different floor and ceiling effects in the way the APS scores are calculated

- differences in the inclusion of vocational qualifications in the statistical definition

- differences in the range of qualifications being offered and studied within schools

- changes in modes of assessment (for example modularisation)

- changes over time in assessment standards

Growth in APS in England and Wales has in been higher in general since 2003/04, when a wider measure of GCSE and equivalent attainment was introduced, and was particularly strong in $2007 / 08$ and $2008 / 09$. Attainment data for Wales is available on both a narrow and wide basis from $2003 / 04$ to $2007 / 08$, which show that growth in each academic year has been considerably higher on the wider measure which includes more qualifications designated as equivalent to GCSEs and GNVQs. It is not known at this stage whether this is a volume effect, through pupils studying for increasing numbers of qualifications, a grade effect, where attainment in the wider equivalent qualifications has been increasing more rapidly than for GCSEs and GNVQs, or a combination of the two. 


\section{Figure 2 Average Point Scores at age 15/16, 1995/96-2008/09}

Great Britain

Index numbers, $1995 / 96=100$

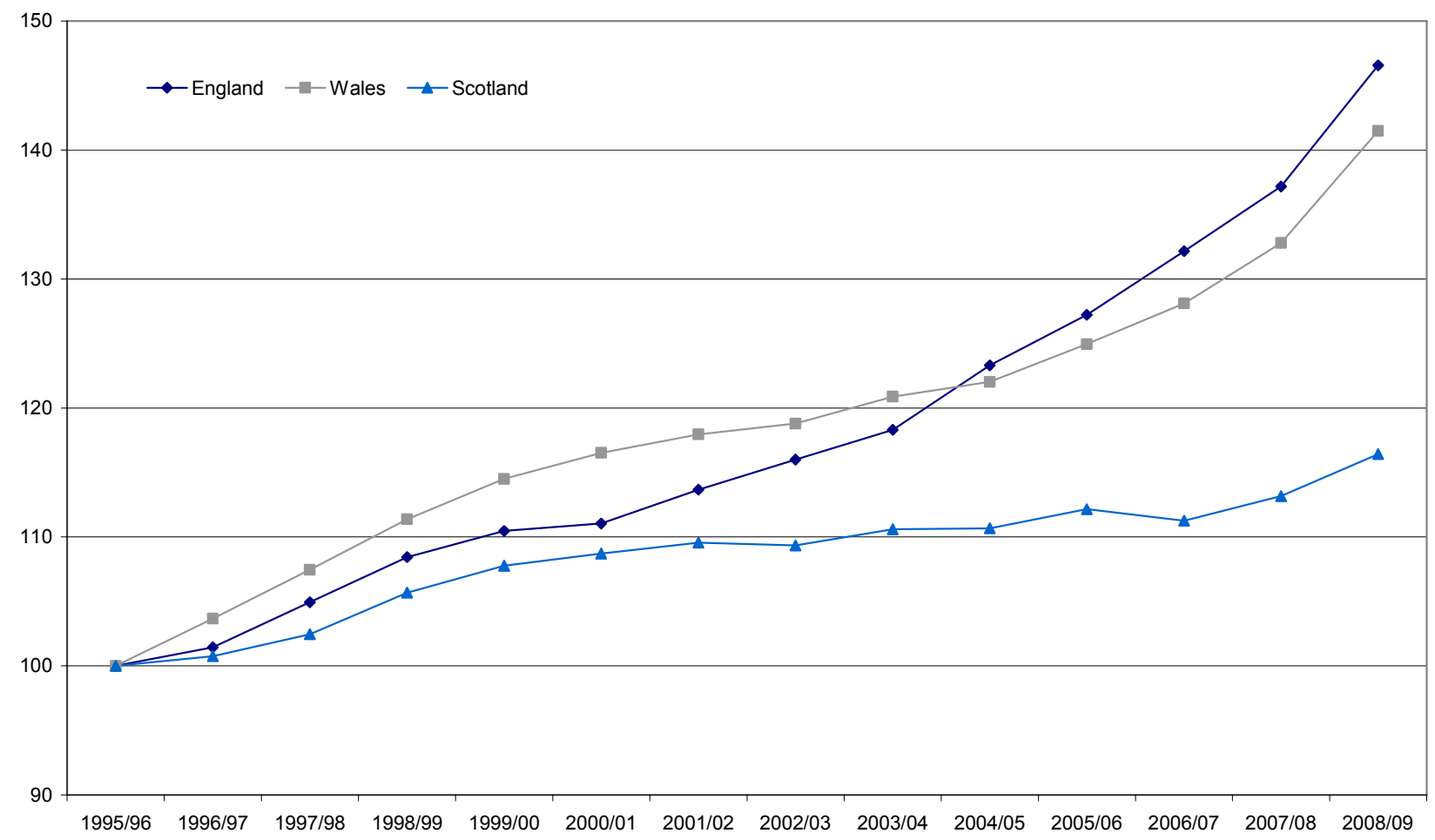

\begin{tabular}{|c|c|c|c|c|c|c|c|c|c|c|c|c|c|c|c|c|c|}
\hline & 1995/96 & 1996/97 & 1997/98 & 1998/99 & 1999/00 & $2000 / 01$ & $2001 / 02$ & $2002 / 03$ & 2003/04 & $2004 / 05$ & $2005 / 06$ & 2006/07 & $2007 / 08$ & 2008/09 & $\begin{array}{c}\text { Average } \\
\text { annual \% } \\
\text { change }\end{array}$ & $\begin{array}{c}\text { APS in } \\
1995 / 96\end{array}$ & $\begin{array}{c}\text { APS in } \\
2008 / 09^{1}\end{array}$ \\
\hline England & 100.0 & 101.5 & 104.9 & 108.4 & 110.5 & 111.0 & 113.7 & 116.0 & 118.3 & 123.3 & 127.2 & 132.2 & 137.2 & 146.6 & 3.0 & 34.4 & 50.4 \\
\hline Wales $^{2}$ & 100.0 & 103.7 & 107.4 & 111.4 & 114.5 & 116.5 & 118.0 & 118.8 & 120.9 & 122.0 & 124.9 & 128.1 & 132.8 & 141.5 & 2.7 & 32.7 & 46.3 \\
\hline Scotland & 100.0 & 100.8 & 102.5 & 105.7 & 107.8 & 108.7 & 109.6 & 109.3 & 110.6 & 110.7 & 112.1 & 111.3 & 113.2 & 116.4 & 1.2 & 153.8 & 179.0 \\
\hline
\end{tabular}

1. APS values in England and Wales from 2003/04 onwards were based on a new scale. Values were converted back to the old scale to allow comparison.

2. APS scores for Wales are only available from 1997/98 onwards and the quality index is estimated for $1995 / 96$ and $1996 / 97$

Source: Department for Education, Welsh Assembly Government, Scottish Executive

In addition to compulsory schooling, ITT is also adjusted for quality using the change in the proportion of final-year students who attain Qualified Teacher Status (QTS) in England. Data are available from 2001/02 and these have been used to construct a quality adjustment that is applied to the whole of the UK. The proportion attaining QTS has increased slightly to around nine in ten, such that the quality adjustment increases ITT output by 0.2 per cent overall between 2001 and 2009.

The validity of using formal examination performance at GCSE level and equivalents as a measure of the quality of education output is often debated. Wider issues of wellbeing for children, such as health and overall personal development are also clearly important. Therefore Table 4 provides triangulation evidence for some wider outcomes of education not fully captured by the use of exam performance. 


\section{Table $4 \quad$ Wider outcomes from education}

\begin{tabular}{|c|c|c|c|c|}
\hline Indicator & $\begin{array}{l}\text { Likely influence of } \\
\text { education sector } \\
\text { (attribution) }\end{array}$ & Key commentary & $\begin{array}{l}\text { Agreement with input, } \\
\text { quantity or quality } \\
\text { changes? }\end{array}$ & Source \\
\hline $\begin{array}{l}\text { Further } \\
\text { Education and } \\
\text { Apprenticeship } \\
\text { success rates }\end{array}$ & $\begin{array}{l}\text { High - measure } \\
\text { relates directly to } \\
\text { education services } \\
\text { received }\end{array}$ & $\begin{array}{l}\text { The success rate for all levels of } \\
\text { FE and apprenticeships rose } \\
\text { between } 2005 / 06 \text { and } 2008 / 09 \\
\text { in England. } \\
\text { The overall learning activity } \\
\text { success rate for FE in Wales } \\
\text { rose between } 2006 / 07 \text { and } \\
2008 / 09 \text {. }\end{array}$ & $\begin{array}{l}\text { Further education quality } \\
\text { not yet measured but } \\
\text { suggests positive link }\end{array}$ & $\begin{array}{l}\text { The data service; } \\
\text { Welsh Assembly } \\
\text { Government }\end{array}$ \\
\hline $\begin{array}{l}\text { Time spent on } \\
\text { physical activity } \\
\text { by children }\end{array}$ & $\begin{array}{l}\text { High - activity in } \\
\text { non-school sports } \\
\text { likely linked to } \\
\text { school sports } \\
\text { participation }\end{array}$ & $\begin{array}{l}\text { The total curriculum time that } \\
\text { pupils in all years spent on } \\
\text { physical education in England } \\
\text { increased between } 2004 / 05 \text { and } \\
2008 / 09 \text {, except for Year } 10 \\
\text { where it remained unchanged. }\end{array}$ & $\begin{array}{l}\text { Uncertain. Sport has } \\
\text { strong impact on health but } \\
\text { impact on achievement } \\
\text { unclear }\end{array}$ & $\begin{array}{l}\text { Department for } \\
\text { Children, Schools and } \\
\text { Families }\end{array}$ \\
\hline Bullying & $\begin{array}{l}\text { High - schools } \\
\text { have key impact on } \\
\text { prevalence of } \\
\text { bullying }\end{array}$ & $\begin{array}{l}\text { The proportions of boys and } \\
\text { girls aged } 11,13 \text { and } 15 \text { years } \\
\text { old reporting having been } \\
\text { bullied at least twice in the } \\
\text { previous two months in } 2005 / 06 \\
\text { broadly fell with age }\end{array}$ & $\begin{array}{l}\text { Uncertain. Positive impact } \\
\text { on inputs through targeted } \\
\text { resources; no time series } \\
\text { evidence to corroborate } \\
\text { changes in bullying with } \\
\text { changes in output }\end{array}$ & $\begin{array}{l}\text { Health Behaviour in } \\
\text { School-aged Children } \\
\text { (WHO collaborative } \\
\text { study) }\end{array}$ \\
\hline $\begin{array}{l}\text { Proportion of } \\
\text { young people } \\
\text { not in } \\
\text { employment, } \\
\text { education or } \\
\text { training }\end{array}$ & $\begin{array}{l}\text { Medium/high - } \\
\text { dependent not only } \\
\text { on level of } \\
\text { educational } \\
\text { achievement but } \\
\text { also socio- } \\
\text { economic factors }\end{array}$ & $\begin{array}{l}\text { The proportion of } 16 \text { to 18-year- } \\
\text { olds in England not in } \\
\text { education, employment or } \\
\text { training (NEET) fell between } \\
1996 \text { and } 2009\end{array}$ & $\begin{array}{l}\text { Agreement with output } \\
\text { figures -improvements in } \\
\text { attainment imply fall in } \\
\text { NEETs. However, state of } \\
\text { economy has a key impact } \\
\text { on labour demand. }\end{array}$ & $\begin{array}{l}\text { Department for } \\
\text { Children Schools and } \\
\text { Family }\end{array}$ \\
\hline Truancy rates & $\begin{array}{l}\text { Medium - schools } \\
\text { can have an impact } \\
\text { on rates of } \\
\text { unauthorised } \\
\text { absence. However, } \\
\text { other factors also } \\
\text { likely to play a role } \\
\text { (socio-economic } \\
\text { background) }\end{array}$ & $\begin{array}{l}\text { Between } 2007 \text { and 2009, the } \\
\text { rates of unauthorised absence } \\
\text { increased slightly in primary and } \\
\text { secondary schools in England }\end{array}$ & $\begin{array}{l}\text { Partial disagreement with } \\
\text { quality measure. Children } \\
\text { who have higher } \\
\text { unauthorised absence } \\
\text { rates also tend to have } \\
\text { lower levels of academic } \\
\text { achievement, however the } \\
\text { impact maybe small due to } \\
\text { smaller proportions. }\end{array}$ & $\begin{array}{l}\text { Department for } \\
\text { Children, Schools and } \\
\text { Families }\end{array}$ \\
\hline Diet and obesity & $\begin{array}{l}\text { Low - diet and } \\
\text { exercise are only } \\
\text { partly influenced by } \\
\text { education or school } \\
\text { meals }\end{array}$ & $\begin{array}{l}\text { The proportion of overweight or } \\
\text { obese children in England } \\
\text { increased between } 1995 \text { and } \\
2008 \text { for both boys and girls }\end{array}$ & $\begin{array}{l}\text { Uncertain. Targeted } \\
\text { resources may increase } \\
\text { inputs but effects on } \\
\text { outcomes not clear }\end{array}$ & $\begin{array}{l}\text { The NHS information } \\
\text { centre for Health and } \\
\text { Social Care }\end{array}$ \\
\hline $\begin{array}{l}\text { Pupils who } \\
\text { regularly or } \\
\text { occasionally } \\
\text { smoke }\end{array}$ & $\begin{array}{l}\text { Low - social } \\
\text { factors likely to play } \\
\text { larger influence } \\
\text { than schools }\end{array}$ & $\begin{array}{l}\text { The percentage of pupils who } \\
\text { regularly or occasionally smoke } \\
\text { in England has fallen by almost } \\
\text { half between } 2001 \text { and } 2009 \text {. }\end{array}$ & $\begin{array}{l}\text { Uncertain. Only small } \\
\text { proportion of school } \\
\text { population. Targeted } \\
\text { resources increase inputs } \\
\text { but effects on outcomes } \\
\text { unclear }\end{array}$ & $\begin{array}{l}\text { The NHS information } \\
\text { Centre for Health and } \\
\text { Social Care }\end{array}$ \\
\hline $\begin{array}{l}\text { Alcohol and } \\
\text { substance } \\
\text { abuse }\end{array}$ & $\begin{array}{l}\text { Low-- social } \\
\text { factors likely to } \\
\text { have more } \\
\text { influence than } \\
\text { schools }\end{array}$ & $\begin{array}{l}\text { The proportion of pupils in } \\
\text { England who have taken any } \\
\text { drug has fallen between } 2001 \\
\text { and } 2008 \text {. The proportion of } \\
\text { pupils who reported that they } \\
\text { drank alcohol at least once a } \\
\text { week fell between } 2001 \text { and } \\
2009 \text { in England. }\end{array}$ & $\begin{array}{l}\text { Uncertain. Targeted } \\
\text { resources may increase } \\
\text { inputs but only small part } \\
\text { of school population }\end{array}$ & $\begin{array}{l}\text { The NHS information } \\
\text { centre for Health and } \\
\text { Social Care }\end{array}$ \\
\hline $\begin{array}{l}\text { Reported } \\
\text { teenage } \\
\text { pregnancies }\end{array}$ & $\begin{array}{l}\text { Very low - social } \\
\text { factors likely to play } \\
\text { much larger } \\
\text { influence than } \\
\text { schools }\end{array}$ & $\begin{array}{l}\text { The number of reported teenage } \\
\text { pregnancies in England and } \\
\text { Wales fell between } 1998 \text { and } \\
2008\end{array}$ & $\begin{array}{l}\text { Uncertain. Small positive } \\
\text { impact on input through } \\
\text { targeted resources but } \\
\text { minimal impact on } \\
\text { outcomes as affects few } \\
\text { pupils }\end{array}$ & $\begin{array}{l}\text { Office for National } \\
\text { Statistics }\end{array}$ \\
\hline
\end{tabular}




\section{Impact of quality-adjustments on education quantity}

Figure 3 illustrates the impact of quality-adjustments on education quantity over the period 1996 to 2009 .

\section{Figure 3 Impact of education quality-adjustments, 1996-2009}

\section{United Kingdom}

Index numbers, $1996=100$

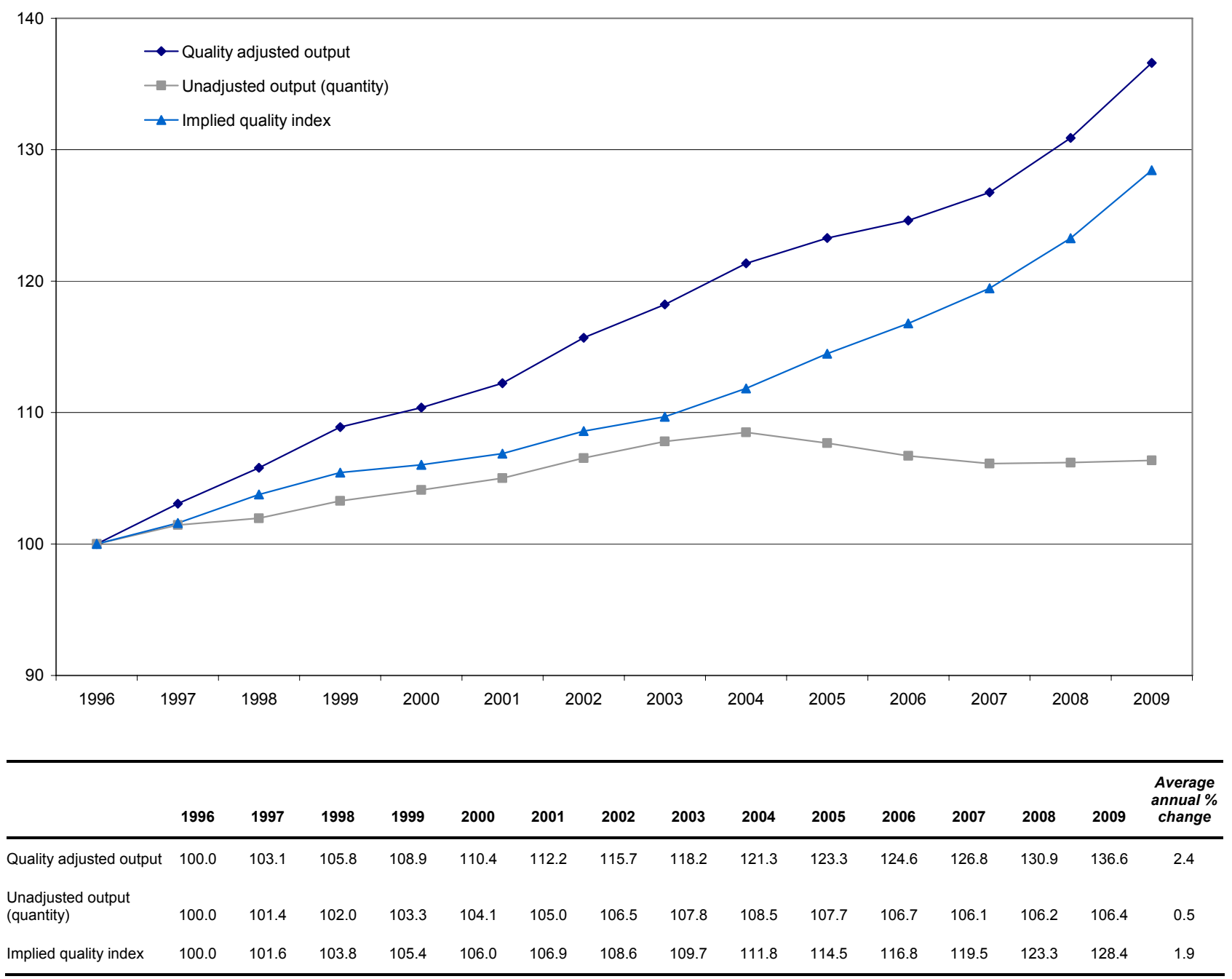

Source: Office for National Statistics

When quality adjustments are applied to education quantity, the overall growth over the period 1996 to 2009 increases from 6.4 to 36.6 per cent, with the average annual percentage change increasing from 0.5 to 2.4 per cent. This difference illustrates the sensitivity of education output to quality adjustment and highlights the importance of selecting the most appropriate adjustment indicator(s). Average annual implied quality growth averaged 1.6 per cent from 1996 to 2007, but more than doubled to 3.7 per cent on average in 2008 and 2009, driven by strong increases in attainment in England and Wales. Other key results include that: 
- output grew by 4.4 per cent in 2009

- growth was strongest between 2007 and 2009, averaging 3.8 per cent annually

- the rise in output is driven by changes in attendance, largely as a result of demographic change, and increases in attainment at age 15/16, particularly in 2008 and 2009

- output growth over the full period was strongest in England, at 39.7 per cent (see Figure 4)

\section{Figure 4 Growth in the volume of education output by country, 1996-2009}

United Kingdom

Index numbers, 1996=100

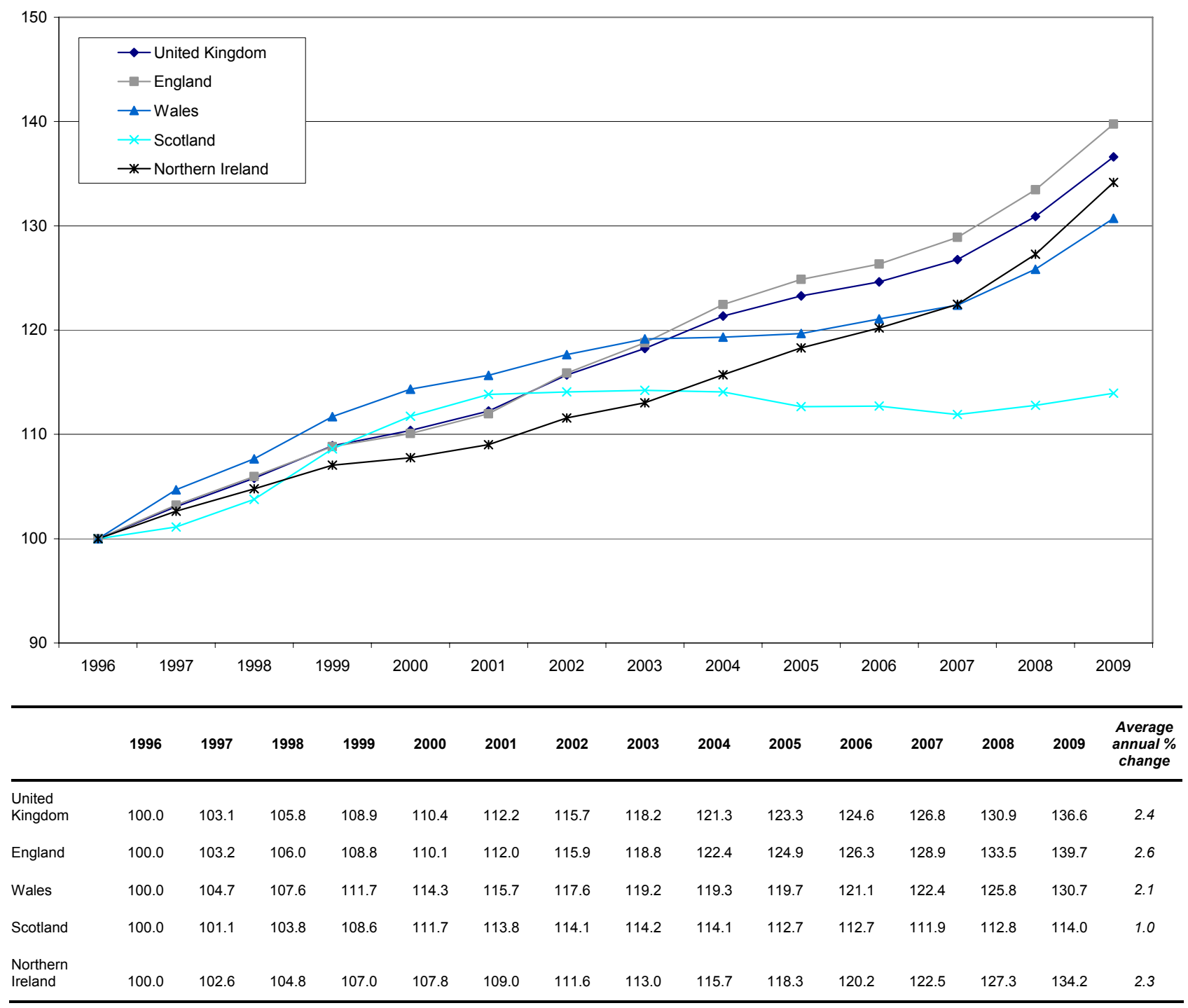

Source: Office for National Statistics 


\section{Education inputs}

\section{Components of education inputs at current prices}

Education inputs have three components: labour (for example teaching staff), goods and services (for example learning materials and electricity), and capital services (for example the flow of services provided by a vehicle or building in a given period).

Expenditure on labour and goods and services is measured in current prices (what was actually paid). Figures for capital services are estimates of the value of the flow of services from education capital. While they do not form an explicit part of publicly funded education expenditure, they represent the annual input provided by capital assets owned and are therefore included alongside actual current expenditure.

Table 5 summarises changes in expenditure on education over the period 1996 to 2009.

\section{Table $5 \quad$ Education input components, current prices, 1996-2009}

United Kingdom

\begin{tabular}{|c|c|c|c|c|c|c|c|c|c|c|c|c|c|c|c|}
\hline & 1996 & 1997 & 1998 & 1999 & 2000 & 2001 & 2002 & 2003 & 2004 & 2005 & 2006 & 2007 & 2008 & 2009 & $\begin{array}{c}\text { Annual } \\
\text { average } \\
\% \\
\text { change }\end{array}$ \\
\hline Labour & 20.8 & 21.4 & 22.1 & 23.4 & 25.3 & 28.3 & 30.8 & 33.3 & 35.6 & 37.7 & 39.4 & 41.2 & 42.3 & 43.5 & 5.8 \\
\hline Goods and Services & 6.9 & 6.7 & 7.0 & 8.0 & 8.4 & 8.8 & 10.2 & 11.2 & 12.4 & 13.6 & 14.6 & 15.9 & 17.8 & 18.4 & 7.9 \\
\hline Capital Services & 3.3 & 3.0 & 3.5 & 3.6 & 3.7 & 4.3 & 4.5 & 4.1 & 3.7 & 4.7 & 5.7 & 6.1 & 7.6 & 8.9 & 8.0 \\
\hline Total & 30.9 & 31.1 & 32.6 & 35.0 & 37.4 & 41.4 & 45.6 & 48.6 & 51.7 & 55.9 & 59.7 & 63.2 & 67.7 & 70.8 & 6.6 \\
\hline
\end{tabular}

Source: Office for National Statistics

Data for the latest year, 2009, are provisional estimates (revised figures will be published in future articles). Education inputs totalled just under $£ 71$ billion in 2009 , including approximately $£ 7.3$ billion on further education inputs. In a revision to previous productivity articles this is the first measure of education inputs to incorporate expenditure on further education for all age groups. This explains the upward revision to education expenditure throughout the time series from previously published data.

In 2009, education was the second largest component of General Government Final Consumption Expenditure (GGFCE), after healthcare. Total education input as defined here makes up around 5 per cent of the expenditure measure of Gross Domestic Product.

The labour and goods and services components are based on:

- GGFCE estimates for education expenditure in the National Accounts

- estimates of expenditure on further education from national further education skills councils and the devolved administrations 
The current price capital component is calculated as part of the experimental Volume Index of Capital Services (VICS) developed by ONS. For further information, see Volume of Capital Services: Estimates for 1950 to 2008 (ONS 2010b).

Labour costs are the largest component of education expenditure. In 2009, at current prices, labour expenditure was $£ 43.5$ billion, approximately two-thirds of the total expenditure that year. Teachers' pay is the largest element of labour costs. Teacher numbers were relatively stable from 1996 to 2009 but expenditure on support staff, particularly teaching assistants, has increased sharply. This was largely driven by government policies and reforms to reduce unpaid overtime worked by teachers by employing additional support staff. Support staff numbers more than doubled between 1996 and 2005. Labour costs also include expenditure on indirect support services, such as staff time on policy development, standards setting, finance and training.

In 2009, £18.4 billion was spent on goods and services, approximately one-quarter of total expenditure on education inputs. This component consists of the goods and services procured from the outside the education sector that are consumed in the production of education services in any given year. This includes items or services such as teaching aids, electricity, building maintenance and transport. Government purchases of initial teacher training, health professional courses and private nursery places are part of the goods and services component.

The smallest component of education inputs is capital services, estimated at £8.9 billion in 2009 , about one-eighth of the total. Goods such as IT equipment and buildings are medium- to longterm investments that can be used for a number of years, and are hence classified as capital items. Capital services quantify the flow of inputs from the capital stock into production, through estimates of rental payments.

\section{Measuring the volume of education inputs}

In current prices, total expenditure on education inputs increased by just under 130 per cent between 1996 and 2009. However, this includes effects caused by pay and price changes. Productivity measurement requires that education inputs are measured in volume terms. Inputs can be measured directly, for example, using hours worked or a measure of staff numbers in the case of labour inputs. Where data do not allow for a direct measure of inputs, a volume measure can be derived by dividing current price spending figures by an appropriate estimate of price (the deflator).

Measuring Productivity, OECD Manual (OECD 2001) recommends that labour inputs should be measured directly. In these estimates, 94 per cent of education labour inputs (by expenditure weight) in the UK are measured in this way. The calculation method uses a breakdown of fulltime-equivalent teaching and support staff numbers (teachers are also adjusted for actual hours worked) and weighted together by average salary. The remaining 6 per cent of labour inputs are measured indirectly, by dividing current price expenditure by an appropriate pay deflator. As this small part is a measure of the inputs of central government staff working in education, the most appropriate pay deflator is the public sector Average Earnings Index (AEI) including bonuses. 
Goods and services inputs are measured indirectly, using appropriate deflators to remove the effect of price changes. Expenditure on goods and services in the UK can be split into expenditure by local authorities (around four-fifths) and central government (around one-fifth). Specific price deflators have been derived for each component using ONS producer, retail and service sector price data.

The capital component is measured using the VICS for local authority and central government education. Further details can be found in ONS (2010b).

Figure 5 summarises changes in the volume of education inputs by component over the period 1996 to 2009.

\section{Figure 5 Volume of education inputs by component, 1996-2009}

\section{United Kingdom}

Index numbers, $1996=100$

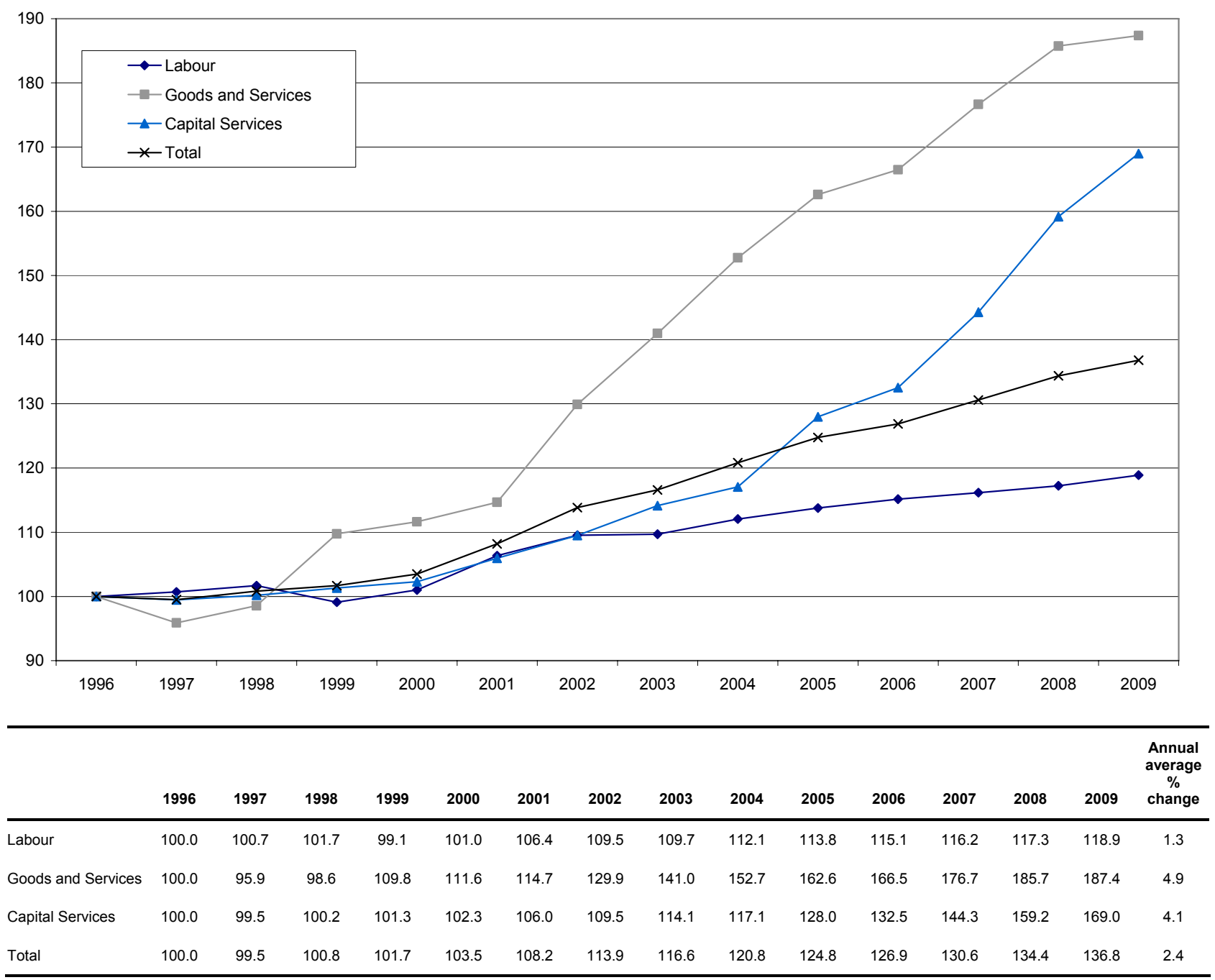

Source: Office for National Statistics 
Latest estimates of inputs, in volume terms, show that:

- between 1996 and 2009, inputs grew by 36.8 per cent, with an annual average increase of 2.4 per cent

- between 2008 and 2009, inputs grew by 1.8 per cent

- between 1996 and 2009, labour inputs grew by 18.9 per cent. Growth in labour inputs contributed 13.5 percentage points to the overall growth in total inputs. The biggest driver of growth in the volume of labour inputs has been the increase in support staff numbers

- between 1996 and 2009 goods and services inputs grew by 87.4 per cent, contributing 17.1 percentage points to the growth in total inputs. Over the same period expenditure in current prices on goods and services increased by 167 per cent

- between 1996 and 2009 and capital services inputs by 69.0 per cent. However due to its relatively small share of total education expenditure capital services only contributes 6.2 percentage points to the overall growth in the volume of inputs.

Table 6 provides some triangulation evidence by discussing four education inputs, how they have changed over time, and whether the strength and direction of the change agree with the education inputs and output figures in this article.

\section{Productivity of education in the UK}

This article updates the estimates of change in productivity of publicly funded education services published alongside estimates for other public services in June 2010 (ONS 2010a).

Latest estimates show that (see Figure 6):

- productivity grew by 2.5 per cent in 2009 , following growth of 0.4 per cent in 2008

- productivity was 0.1 per cent lower than it was in 1996; this is because over the whole period

- output grew by 36.6 per cent, with an annual average increase of 2.4 per cent, and

- inputs grew by 36.8 per cent, with an annual average increase of 2.4 per cent 


\section{Table $6 \quad$ Inputs to education - other evidence}

\begin{tabular}{|c|c|c|c|c|}
\hline Indicator & $\begin{array}{l}\text { Likely influence } \\
\text { of education } \\
\text { sector } \\
\text { (attribution) }\end{array}$ & Key commentary & $\begin{array}{l}\text { Agreement with input, } \\
\text { quantity or quality } \\
\text { changes? }\end{array}$ & Source \\
\hline $\begin{array}{l}\text { Teaching } \\
\text { standards }\end{array}$ & $\begin{array}{l}\text { Very high - } \\
\text { measure relates } \\
\text { directly to } \\
\text { schools }\end{array}$ & $\begin{array}{l}\text { Between } 2005 / 06 \text { and } \\
2008 / 09, \text { the proportion of } \\
\text { primary and secondary } \\
\text { schools in which teaching } \\
\text { was rated 'good' or above } \\
\text { increased in both England } \\
\text { and Wales. }\end{array}$ & $\begin{array}{l}\text { Corroborates increases in } \\
\text { school quality measures and } \\
\text { increase in quality-adjusted } \\
\text { output }\end{array}$ & $\begin{array}{l}\text { England - Ofsted } \\
\text { Annual Report } \\
2008 / 09 \\
\text { Wales - Estyn } \\
\text { Annual Report }\end{array}$ \\
\hline $\begin{array}{l}\text { Class sizes, } \\
\text { pupil-teacher } \\
\text { ratios and } \\
\text { pupil-adult } \\
\text { ratios }\end{array}$ & $\begin{array}{l}\text { High - class } \\
\text { sizes and ratios } \\
\text { can adjust to } \\
\text { reflect changes } \\
\text { in the school- } \\
\text { aged population }\end{array}$ & $\begin{array}{l}\text { Between } 2000 / 01 \text { and } \\
2006 / 07, \text { class sizes for } \\
\text { primary schools in England, } \\
\text { Wales, Scotland and } \\
\text { Northern Ireland fell; class } \\
\text { sizes for secondary schools } \\
\text { in England and Wales fell } \\
\text { between the same period; } \\
\text { between } 1995 / 96 \text { and } \\
2008 / 09 \text { pupil-teacher ratio } \\
\text { for all schools in the UK fell. } \\
\text { Between } 2000 / 01 \text { and } \\
2008 / 09 \text { the pupil-adult ratio } \\
\text { fell in England, Wales and } \\
\text { Scotland for primary and } \\
\text { secondary schools. }\end{array}$ & $\begin{array}{l}\text { Evidence from literature on } \\
\text { the impact of class size and } \\
\text { pupil ratios on attainment } \\
\text { unclear; Corroborates rise in } \\
\text { inputs through increase in } \\
\text { teachers and support staff }\end{array}$ & $\begin{array}{l}\text { Department of } \\
\text { Education and } \\
\text { Skills; Welsh } \\
\text { Assembly } \\
\text { Government; } \\
\text { Scottish } \\
\text { Government; } \\
\text { Northern Ireland } \\
\text { Department of } \\
\text { Education }\end{array}$ \\
\hline $\begin{array}{l}\text { Pupil- } \\
\text { computer } \\
\text { ratios }\end{array}$ & $\begin{array}{l}\text { Medium- } \\
\text { schools can } \\
\text { have an impact } \\
\text { on availability of } \\
\text { computers; } \\
\text { however, access } \\
\text { at home is also } \\
\text { likely. }\end{array}$ & $\begin{array}{l}\text { The number of pupils per } \\
\text { computer has fallen between } \\
2000 \text { and } 2009 \text { for primary } \\
\text { and secondary schools in } \\
\text { England }\end{array}$ & $\begin{array}{l}\text { Positive impact on input } \\
\text { growth via procurement. } \\
\text { Some new studies have } \\
\text { shown a positive relationship } \\
\text { between technology and } \\
\text { learning outcomes. For } \\
\text { instance, a study by the } \\
\text { Institute for Fiscal Studies } \\
\text { shows that computer and } \\
\text { internet access at home is } \\
\text { important in explaining the } \\
\text { achievement gap, and plays } \\
\text { a role in some behaviour } \\
\text { outcomes. }\end{array}$ & $\begin{array}{l}\text { Becta Review, } \\
\text { Department for } \\
\text { Education and } \\
\text { Skills }\end{array}$ \\
\hline $\begin{array}{l}\text { Special } \\
\text { Education } \\
\text { Needs }\end{array}$ & $\begin{array}{l}\text { Medium - } \\
\text { Reflects the level } \\
\text { of additional } \\
\text { support required } \\
\text { from schools }\end{array}$ & $\begin{array}{l}\text { Since } 2003 \text {, the proportion of } \\
\text { pupils with a statement of } \\
\text { special education needs has } \\
\text { slightly decreased. However, } \\
\text { there is an increase in } \\
\text { numbers requiring School } \\
\text { Action/School Action Plus to } \\
18.2 \% \text { (from } 14 \% \text { in } 2003 \text { ). } \\
\text { Reports of some problems } \\
\text { with quality of additional } \\
\text { support given to children and } \\
\text { a lack of evaluation of } \\
\text { effectiveness. Some } \\
\text { evidence of poor overall } \\
\text { teaching and pastoral support } \\
\text { leading to unnecessary SEN } \\
\text { interventions. }\end{array}$ & Supports increase in inputs. & $\begin{array}{l}\text { Ofsted review of } \\
\text { special } \\
\text { educational } \\
\text { needs and } \\
\text { disability, } 2010\end{array}$ \\
\hline
\end{tabular}




\section{Figure $6 \quad$ Growth in education output, inputs and productivity estimates, 1996-2009}

United Kingdom

Index numbers, $1996=100$

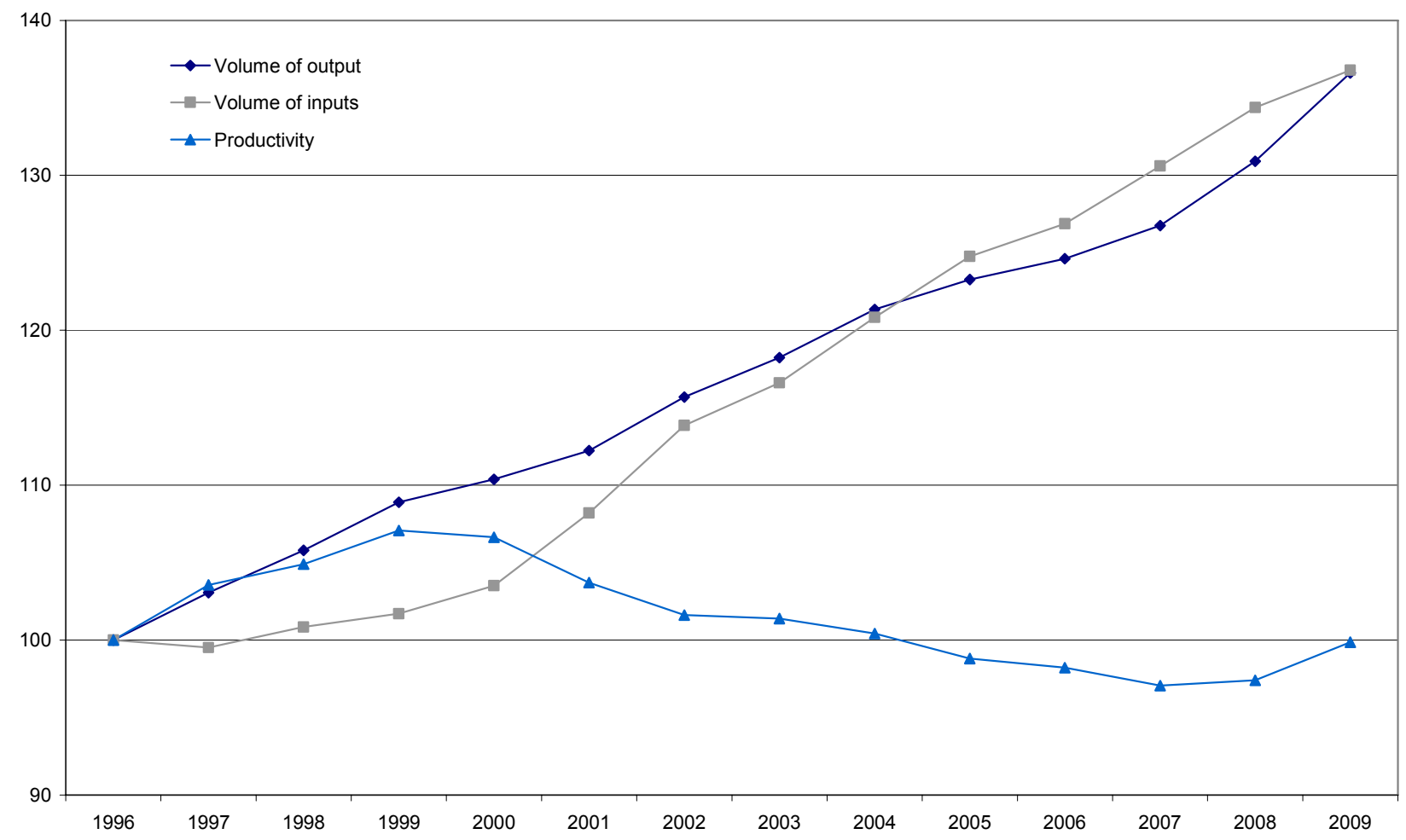

\begin{tabular}{|c|c|c|c|c|c|c|c|c|c|c|c|c|c|c|c|}
\hline & 1996 & 1997 & 1998 & 1999 & 2000 & 2001 & 2002 & 2003 & 2004 & 2005 & 2006 & 2007 & 2008 & 2009 & $\begin{array}{c}\text { Annual } \\
\text { average \% } \\
\text { change }\end{array}$ \\
\hline $\begin{array}{l}\text { Volume of } \\
\text { output }\end{array}$ & 100.0 & 103.1 & 105.8 & 108.9 & 110.4 & 112.2 & 115.7 & 118.2 & 121.3 & 123.3 & 124.6 & 126.8 & 130.9 & 136.6 & 2.4 \\
\hline $\begin{array}{l}\text { Volume of } \\
\text { inputs }\end{array}$ & 100.0 & 99.5 & 100.8 & 101.7 & 103.5 & 108.2 & 113.9 & 116.6 & 120.8 & 124.8 & 126.9 & 130.6 & 134.4 & 136.8 & 2.4 \\
\hline Productivity & 100.0 & 103.6 & 104.9 & 107.1 & 106.6 & 103.7 & 101.6 & 101.4 & 100.4 & 98.8 & 98.2 & 97.1 & 97.4 & 99.9 & 0.0 \\
\hline
\end{tabular}

Source: Office for National Statistics

\section{Productivity change in detail}

From 1996 to 2009, publicly funded education productivity in the UK declined by 0.1 per cent. But this marginal fall overall masks three periods of greater change:

- from 1996 to 1999, productivity grew by 7.1 per cent, with an annual average increase of 2.3 per cent. In this period there was strong output growth, due to growth in the school age population, but only weak growth in inputs 
- from 1999 to 2007, productivity fell by 9.4 per cent, an annual average fall of 1.2 per cent. Growth in school attendance, once adjusted for quality, was outstripped by a sharp rise in inputs, mainly through the employment of more school support staff

- from 2007 to 2009, productivity grew by 2.9 per cent, with an annual average increase of 1.4 per cent, as output grew faster than inputs, due mainly to relatively large improvements in pupil attainment at age 15/16 in England and Wales

The pattern of productivity change in the UK, which is dominated by changes in England, reflects a number of factors including:

- changes in the secondary-school-age population in the UK, which increased from 1996 to 2004 then declined from 2005 to 2009, and changes in the UK primary school age population, which fell sharply from 1998 to 2009 . These changes reduced education quantity. Where it was not locally feasible to close schools or reduce the number of classes, measured productivity will have fallen if fixed and semi-fixed input costs were spread over fewer pupils

- improved attendance rates in the UK from 1996 to 2009, and improvements in GCSE and equivalents and Standard Grades. These changes increased education output as they more than offset the decline in the school age population; particularly in the case of attainment which grew relatively rapidly in England and Wales in 2008 and 2009. Attainment growth in both countries was higher in general from 2003/04 onwards, when measures were widened to include additional equivalent qualifications

- a large increase in the number of support staff between 1996 and 2009, which in recent years was likely influenced by the agreement in 2003 between UK governments, employers organisations and unions of a work reform package, intended to reduce teacher workload. This change has increased education inputs

- Rapid expansion in both publicly funded nursery provision and health professional students. Publicly funded nursery provision increased following the introduction of policies in UK countries providing a number of hours of free childcare per week for three- and four-year-olds, while the rise in health professional students has been driven mainly by trainee nurses, particularly at degree level

Productivity change may also reflect:

- increases in inputs, such as greater support staff numbers or initiatives to improve well-being, that may improve the quality of education in ways not currently captured by the quality adjustment. For example, through support helping the integration of pupils with special needs

- the extent to which inputs are targeted at lower-achieving pupils and other groups on equity grounds. This may affect productivity change if it is harder or easier to achieve improvements for these groups

- time lags, which mean that some changes in resources, including expansion in pre-school education, may not yet have had any impact on the current quality measure 


\section{Next Steps}

ONS plans to continue work with Department for Education (DfE), the Department for Business, Innovation and Skills (BIS), education departments in the devolved administrations and others on a number of developments.

\section{Improvements to the quantity measure}

- gather and compare more comprehensive data on school sessions and hours of education services delivered in order to improve on, if possible, the accuracy of the current attendancebased quantity measure

- identify publicly funded output from higher education institutions, accounting for the fee and transfer arrangements in each of the devolved administrations and the publicly funded research work that universities undertake, as well as the number of students they teach

\section{Improvements to the quality adjustment}

- review, alongside external evidence, the use of GCSEs and equivalent qualifications, and Standard Grades, to quality-adjust primary and secondary education quantity

- present, in the next education productivity article, a potential quality adjustment for Further Education based on retention and achievement (success) data

\section{Improvements to the measure of the volume of inputs}

- improve the inputs measure of further education, for example by investigating whether expenditure data are available for the three components of further education inputs, which deflators may be appropriate and whether a direct labour measure could be calculated

- periodically review and improve the inputs measures, as required

\section{Contact}

elmr@ons.gov.uk

\section{References}

Atkinson T (2005) Atkinson Review: Final Report: Measurement of Government Output and Productivity for the National Accounts, Palgrave Macmillan: Basingstoke.

Eurostat (2001) Handbook on Price and Volume Measures in National Accounts, available at: epp.eurostat.ec.europa.eu/portal/page/portal/product_details/publication?p_productcode=KS-4101-543

OECD (2001) Measuring Productivity, OECD Manual, available at:

www.oecd.org/dataoecd/59/29/2352458.pdf 
ONS (2007) Methods for Public Service Productivity: Quality Adjusting School Education Output, available at:

www.ons.gov.uk/aboutstatistics/ukcemga/publicationshome/publications/archive/methods-forpublic-service-productivity--quality-adjusting-school-education-output.pdf

ONS (2009) Public Service Output, Input and Productivity: Education, available at: http://www.statistics.gov.uk/cci/article.asp?ID=2327

ONS (2010a) Total Public Service Output and Productivity, available at: www.statistics.gov.uk/articles/nojournal/TotalPublicServiceFinalv5.pdf

ONS (2010b) Volume of Capital Services: Estimates for 1950 to 2008, available at: www.statistics.gov.uk/statbase/product.asp?vlnk=14205

Stokoe P (2010) Classification of sixth form and further education institutions, available at www.statistics.gov.uk/about/methodology_by_theme/sixth-form.asp 